\title{
Supporters of the disabled should demand Latimer's release
}

$\mathrm{W}$ hy do advocates for the disabled continue to harass Robert Latimer for ending the suffering of his I2-year-old daughter, Tracy? Rather than fighting for Latimer's continued confinement these organizations and individuals should be shouting to the high heavens for his release.

Surely, those who are most familiar with the hellish problems facing the disabled and their caregivers, should be the first to leap into Latimer's corner. After all, such knowledge usually triggers empathy.

Instead, Canadian newspapers featured a plethora of letters to the editor from caregivers and articles quoting advocacy organizations all supporting the National Parole Board's decision in December to deny Latimer day-parole. The spokesperson for the Canadian Association for Community Living, for example, called Latimer's "profound" lack of remorse "deeply disturbing." Elsewhere, an individual stated that condoning Tracy's death is the start of the slippery slope where no disabled person would be safe. ${ }^{2}$

Where, one has to inquire, is the empathy for the suffering of this child among these advocates for the disabled?

Back in a 200I, I wrote in my newspaper column, "The Doctor Game," that before the Supreme Court of Canada's 4 wise men and 3 wise women sent Latimer to jail they should have paused for several days. Why? So that each one of the justices who had condemned Latimer could look after a similar child. They would quickly realize the horrible rigours involved in caring for a child suffering from cerebral palsy in a rural farmhouse, caring for a child who is spastic, quadriplegic and immobile, a q child who had suffered through several operations, whose pain could not be controlled, and who was having as many as 6 epileptic attacks a day causing dislocation of her hips. A child who could not communicate her pain. I believe this would have convinced these justices that this family did indeed face psychological trauma and that it was mercy, not murder that motivated Latimer.

Surely the disabled, more than any other people should be able to understand and, through their advocates, articulate Latimer's torment.

Some of these advocates for the disabled defend their views on Latimer in part by saying that Tracy was not capable of giving informed consent. This is a feeble argument and hypocrisy at its worse. We all know that even if Tracy had been a Rhode's Scholar, fully capable of giving informed consent, they still would have objected. In the view of these groups, mercy killing is murder regardless of consent.

Surely, in the name of humanity, these advocates for the disabled should show enough decency not to tar Latimer with the same judicial brush as the current scoundrels that infect our society, the young punks who commit violent crimes and receive unbelievable short sentences.

It is also high time that those with a disability question the motives and philosophy of those who speak on their behalf. Do they truly represent their feelings on this issue? I doubt it. Following my articles denouncing the Supreme Court of Canada's decision I received a volume of mail from people from all walks of life. A minority of readers vehemently disagreed with me. The majority, which included many people living with a disability, thought the law was an elephantine ass, a national disgrace. The overall sentiment was that society should acknowledge that in Latimer, we are not dealing with a hardened criminal. Rather, he is a hard-working farmer who loved his daughter and who could not bear to see her suffer any longer.

Surely it is time for the advocates for the disabled to realize that the justice system, in this particular case, has stepped outside the bounds of common sense. And that keeping Latimer in jail now amounts to persecution rather than prosecution.

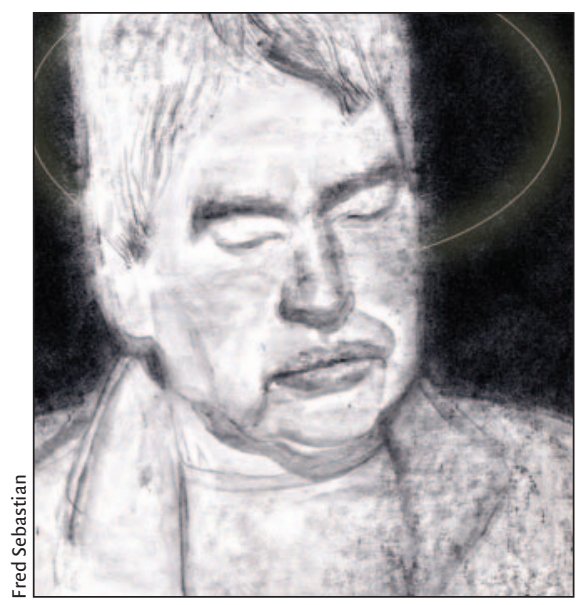

Advocates for the disabled would receive great praise from the public if they reversed their stance, and openly agree with the majority of Canadians that Robert Latimer is neither a Paul Bernardo nor a Clifford Olsen.

Or does this logic fall on deaf ears? Do we have to conclude that a small group of armchair ethicists within these organizations will demand that this illogical, insane injustice continues?

\section{Ken Walker MD \\ Toronto, Ont.}

Dr. Walker writes a weekly column, The Doctor Game, that is published in 60 Canadian newspapers.

\section{REFERENCES}

I. Hunter J. Latimer: 'I still don't feel guilty.' Globe and Mail [Toronto] 2007 Dec 6; Sect A:Io

2. Serup J. Euthanasia 'a slippery slope' [letter]. Prince George Citizen 2007 Dec 17. Available: www.princegeorgecitizen.com/index.php?option= com_content\&task=view\&id $=108455 \&$ Itemid $=264$ (accessed 2008 Jan I5).

This is the second in a 2-part series on the Latimer controversy; in the Jan. 29, 2008, issue Tom Koch presented an opposing view. If you have an opinion on this issue, please post your views at www.cmaj.ca. Salon contributors are welcome to send a query to salon@cma.ca 